\title{
PENGUJIAN CONFIRMATORY FACTOR ANAYSIS ALAT UKUR UWES- SS VERSI INDONESIA
}

\author{
Santi Yudhistira ${ }^{1}$, Sri Tiatri ${ }^{2}$, dan Heni Mularsih ${ }^{3}$ \\ ${ }^{1}$ Fakultas Psikologi, Universitas Tarumanagara Jakarta \\ Email: santyyudhistira@gmail.com \\ ${ }^{2}$ Fakultas Psikologi, Universitas Tarumanagara Jakarta \\ Email: sri.tiatri@untar.ac.id \\ ${ }^{3}$ Fakultas Psikologi, Universitas Tarumanagara Jakarta \\ Email: henim@mku.untar.ac.id
}

\begin{abstract}
ABSTRAK
Penelitian ini merupakan pengujian confirmatory factor analysis alat ukur academic engagement yaitu Utrecht Work Engagement Scale Student Survey (UWES-SS) 17 ke dalam versi Indonesia. Academic engagement merupakan sikap positif dan fulfilling dalam pekerjaan yang kaitan dengan pikiran mahasiswa yang dikarakteristikan oleh vigor, dedication, dan absorption. Data diambil pada 164 orang mahasiswa Fakultas Psikologi disalah satu universitas negeri di Tangerang Selatan dengan sampel acak. Academic engagement merupakan materi pengembangan dari work engagement yang telah diadaptasi ke dalam berbagai bahasa dari berbagai negara dan diukur dengan grup sample yang berbeda pula. Proses adaptasi dan pengembangan alat ukur UWES-SS 17 terdiri dari tahapan: 1) translation, 2) back translation, 3) adaptasi bahasa sesuai dengan kesesuaian bahasa Indonesia yang baik dan benar, 4) face validity, 5) content validity, 6) pengumpulan data, 7) pengolahan data berupa Uji Model CFA dengan menggunakan software M-Plus 7, dan 8) melakukan analisis data. Berdasarkan uji CFA model I (first order) didapatkan hasil vigor (P.value 0.2728, CFI 0.993, TLI 0.985, RMSEA 0.039), dedication (P.value 0.7781, CFI 1.000, TLI 1.014 RMSEA 0.000), absorption (P.value 0.9216, CFI 1.000, TLI 1.057, RMSEA 0.000) dan hasil uji model 2 (second order) terhadap alat ukur UWES-SS 17. Kedua model dan ketiga dimensi dikatakan fit dan bekerja sesuai dengan teori academic engagement. maka didapatkan hasil P.value 0.0737, CFI 0.982, TLI 0.977, RMSEA 0.035. Berdasarkan hasil uji CFA tersebut dapat disimpulkan bahwa dari 17 butir pernyataan yang diajukan kepada partisipan, maka 16 butir dinyatakan signifikan, dan satu butir yang tidak signifikan. Dengan demikian, UWES-SS merupakan alat ukur yang representatif dan efisien untuk mengukur academic engagement pada kalangan mahasiswa.
\end{abstract}

Kata kunci: UWES-SS 17, Academic Engagement, Confirmatory Factor Analysis, Mahasiswa

\section{PENDAHULUAN Latar Belakang}

Selama tujuh dekade terakhir, para peneliti dan pendidik telah menunjukkan minat yang besar dalam konsep academic engagement yang dikembangkan oleh Schaufeli, Salanova, GonzalezRoma, \& Baker pada tahun 2002 (dikutip dalam Alrashidi, Phan \& Ngu, 2016) sebagai cara untuk memperbaiki ketidakpuasan, mencegah kebosanan peserta didik baik siswa maupun mahasiswa, untuk meningkatkan motivasi siswa. Ryan dan Patrick (dikutip dalam Salmela-Aro \& Upadyaya, 2014) mengungkapkan bahwa keterlibatan dengan tugas sekolah sangat penting bagi keberhasilan dan pengembangan pendidikan siswa untuk menjadi anggota masyarakat yang kompeten. Keterlibatan dalam kegiatan yang berhubungan dengan akademik merupakan cara untuk meningkatkan tingkat keberhasilan siswa, dan perkembangan positif siswa (Alrashidi, Phan \& Ngu, 2016).

Pada awalnya, konsep engagement dirancang dan dikaitkan dengan "work", tetapi baru-baru ini gagasan study engagement (academic engagement) diperkenalkan. Dari sudut pandang psikologis, aktivitas akademik dapat dianggap sebagai "work" (Salanova, Schaufeli, Martínez, \& Bresó, 2010). Sama seperti karyawan, mahasiswa terlibat dalam aktivitas terstruktur dan koersif (misalnya menghadiri kelas) yang mengarah pada sasaran tertentu (misalnya lulus ujian). Jadi 
academic engagement juga ditandai dengan perasaan kuat terhadap tugas, berdedikasi pada studi, dan menyerap informasi yang berkaitan dengan tugas (Ouweneel, Schaufeli, \& Blanc, 2013).

Academic engagement di kalangan mahasiswa universitas dikemukakan oleh Schaufeli, Salanova, Gonzalez-Roma, \& Baker pada tahun 2002. Proses academic engagement ini merupakan perasaan positif dan kepuasan terhadap studi atau akademik (Soini \& Salmela-Aro, 2014). Engagement merupakan suatu proses yang menuntut mahasiswa untuk memperhatikan hal-hal yang dikaji di kelas, selalu hadir di kelas, mengerjakan tugas yang diberikan, mengikuti ujian yang harus ditempuh dan hal lainnya yang mencerminkan keterlibatan penuh mahasiswa dalam proses pembelajaran (Aslamawati, Enoch, \& Halimi, 2015). Proses academic engagement ini merupakan perasaan positif dan kepuasan terhadap studi atau akademik (Soini \& SalmelaAro, 2014). Academic engagement juga merupakan sikap positif dan fulfilling dalam pekerjaan yang kaitan dengan pikiran mahasiswa yang dikarakteristikan oleh vigor, dedication, dan absorption (Schaufeli, Salanova, Gonzalez-Roma, \& Baker, 2002 dikutip dalam Stoeber, Childs, Hayward, \& Feast, 2011; Shih, 2012).

Vigor merupakan tingkat energi dan ketahanan yang tinggi, kesediaan dan kemampuan individu untuk menginvestasikan usaha dalam akademik, dan ketekunan dalam menghadapi kesulitan. Dedicaction yaitu keterlibatan yang kuat dalam akademik, disertai dengan rasa penting terhadap tugas, menunjukkan antusiasme, kebanggaan, dan inspirasi. Absorption yaitu adanya perasaan senang dan tidak dapat melepasakan diri dari pekerjaan atau tugas (Salanova, Schaufeli, Martínez, \& Bresó, 2010; Shih, 2012; Ouweneel, Blanc, \&Schaufeli 2014; Alarcon, Edwards, \& Menke, 2011).

Academic engagement dengan tiga dimensi yang tercermin dalam aspek vigor, dedication, dan absorption (Balducci, Fraccaroli, \& Schaufeli, 2010) masuk ke dalam Utrecht Work Engagement Scale (Seppala, et.al, 2009) yang telah dikembangkan ke dalam format Student Survey (Schaufeli, Martinez, Pinto, Salanova, \& Bakker, 2002). Pengembangan alat ukur Utrecht Work Engagement Scale ke dalam format Student Survey dikenal dengan sebutan Utrecht Work Engagement Scale Student Survey (UWES-SS).

Dimensi ini merupakan konstruksi yang terpisah, tetapi saling berkorelasi tinggi satu sama lain. Baru-baru ini, pemeriksaan mengenai dimensi academic engagement dalam konsep pendidikan yang komprehensif menunjukkan bahwa academic enagegement lebih baik dalam menggambarkan keterlibatan akademik seseorang dibandingkan dengan teori school engagement. Mahasiswa di universitas lebih dapat tergambarkan diferensiasinya keterlibatan dalam akademiknya karena hampir serupa dengan work engagement (Soini \& Salmela-Aro, 2013).

Academic engagement merupakan materi pengembangan baru dari work engagement, tetapi belum mendapat perhatian sebanyak work engagement (Zhang, shi, Yun, Li, Wang, He, Miao, 2014). Meskipun demikian, perhatian terhadap academic engagement telah meningkat dari waktu ke waktu. UWES-SS telah diadaptasi ke dalam berbagai bahasa dari berbagai Negara dan diukur dengan grup sample yang berbeda pula (Seppala, et al., 2009). 
Utrecht Work Engagement Scale Student Survey (UWES-SS) memiliki dua versi pengembangan (Seppala, et.al, 2009). Versi pertama memiliki 17 butir pernyataan dan versi kedua memiliki 9 butir pernyataan (Seppala, et.al, 2009; Balducci, et.al, 2010). Kedua versi UWES-SS memiliki tiga dimensi yang sama, yaitu vigor, dedication, dan absorption, tetapi dengan jumlah butir pernyataan yang berbeda. Pada UWES-SS 9 jumlah butir pernyataannya terdiri dari 3 butir vigor, 3 butir dedication, dan 3 butir absorption (Balducci, et.al, 2010). Sedangkan UWES-SS 17 jumlah butir pernyataannya terdiri dari 6 butir vigor, 5 butir dedication, dan 6 butir absorption (Schaufeli, Salanova, Roma, Bakker, 2001).

Pada awalnya UWES memiliki 24 butir pernyataan. Setelah proses uji statistik dan psikometri, tersisa 17 butir pernyataan yang dapat dipertahankan. UWES 17 inilah yang dikembangkan ke dalam format student survey dan diadaptasi ke dalam berbagai bahasa di berbagai Negara seperti Australia, Belgia, Canada, Prancis, Jerman, Belanda, dan beberapa Negara lainnya. Hasil uji psikometri dan statistik dari setiap Negara berbeda-beda. Beberapa butir pernyataan dari UWESSS 17 gugur sehingga menghasilkan UWES-SS 9. UWES-SS 9 menghasilkan analisis yang stabil dari model CFA yang diujikan. Sembilan butir pernyataan dari UWES-SS 9 fit dan signifikan dalam mengukur masing-masing dimensi dari berbagai Negara (Seppala, et.al, 2009).

Alat ukur mengenai academic engagement belum banyak diadaptasi ke dalam versi bahasa Indonesia. Belum banyak pula penelitian mengenai academic engagement yang diteliti di kalangan mahasiswa. Engagement yang banyak dikembangkan di Indonesia adalah engagement dalam lingkup sekolah, baik itu student engagement maupun school engagement dengan dimensi cognitive engagement, emotional engagement, dan behavior engagement. Ketiga dimensi ini memiliki dasar teori yang berbeda dengan academic engagement yang dikembangkan dalam penelitian ini. Academic engagement ini dianggap lebih baik dalam mengukur keterlibatan mahasiswa mapun siswa di wilayah academic karena mengukur dengan cara memposisikan tugas akademik seperti "work" sehingga dapat digambarkan dan diteliti dengan lebih tepat (Soini \& Salmela-Aro, 2013).

Apabila diuraikan kembali kepada teori work engagement dalam lingkup kerja yang merupakan teori awal academic engagement, alat ukur UWES sudah di adapatasi oleh beberapa peneliti di Indonesia. Salah satu penelitian mengenai pengembangan alat ukur UWES versi Indonesia adalah penelitian yang dikemukakan oleh Titien (2016). Dalam penelitian tersebut, Titien menfokuskan pengembangan UWES kepada validitas isi dan konstrak. Titien mengembangkan alat ukur UWES menjadi 32 pernyataan yang telah di judgment oleh 15 ahli sebagai validitas isi. Titien melakukan uji reliabilitas menggunakan Alpha Cronbach dan validitas menggunakan CFA. Dari hasil uji CFA, dari 32 butir yang di ujikan, tersisa hanya 8 butir yang dinyatakan signifikan, yaitu 4 butir vigor, 2 butir dedication, dan 2 butir absortion (Titien, 2016).

Apabila dibandingkan dengan penelitian tersebut, maka dapat dilihat bahwa tingkat signifikansi butir soal dalam penelitian ini lebih tinggi dibandingkan penelitian sebelumnya sehingga lebih banyak butir soal yang dapat mewakili masing-masing dimensi. Meskipun demikian, penelitian yang dikemukakan oleh Titien menggunakan jenis sampel yang berbeda dengan penelitian ini. Titien menggunakan sampel karyawan dengan konsep teori "work" sedangkan penelitian ini menggunakan sampel mahasiswa dengan konsep teori "academic", dengan demikian kontribusi yang dihasilkanpun berbeda.

Penelitian ini lebih menitikberatkan kontribusi penelitian pada lingkungan pendidikan sebagai studi mengenai keterikatan mahasiswa dalam mengelola tugas-tugas akademik. Peneliti hingga saat ini belum menemukan literatur yang telah membahas peengembangan alat ukur UWES 
dalam format student survey. Berdasarkan perbedaan dimensi tersebut, peneliti tertarik untuk melakukan pengembangan alat ukur academic engagement sebagai alat untuk mengetahui keterikatan akademik mahasiswa dengan lebih baik melalui metode uji model confirmatory factor analysis (CFA).

\section{METODE PENELITIAN \\ Partisipan Penelitian}

Teknik pengambilan sampel yang digunakan yaitu simple random sampling. Populasi partisipan dalam penelitian ini adalah mahasiswa Fakultas Psikologi di salah satu universitas negeri di Tangerang Selatan yang tidak dibatasi jenis kelamin, suku bangsa, agama, dan usia. Jumlah populasi sebanyak 667 orang mahasiswa. Jumlah partisipan sebagai sampel dalam penelitian ini sebanyak 164 orang mahasiswa, yang terdiri dari 35 orang laki-laki (21.34\%) dan 129 orang perempuan $(78,66 \%)$. Pengambilan data dilakukan dengan cara membagikan kuesioner UWESSS 17 versi Indonesia kepada mahasiswa. Adapun gambaran usia partisipan terdiri dari 16 orang berusia 18 tahun (9.76\%), 61 orang berusia 19 tahun (37.19\%), 65 orang berusia 20 tahun (39.63\%), 15 orang berusia 21 tahun (9.15\%), 4 orang berusia 22 tahun (2.44\%), 2 orang berusia 23 tahun $(1.22 \%)$, dan 1 orang berusia 24 tahun $(0.61 \%)$.

\section{Pengukuran}

Penelitian ini menggunakan metode kuantitatif untuk mengembangkan alat ukur. Alat ukur yang dikembangkan adalah Utrecht Work Engagement Scale Student Survey 17 (UWES-SS 17) yang telah diadaptasi ke dalam bahasa Indonesia berdasarkan teori Academic engagement di kalangan mahasiswa yang diperkenalkan oleh Schaufeli, Salanova, Gonzalez-Roma, dan Baker pada tahun 2002. UWES-SS 17 memiliki tiga dimensi yaitu: vigor dengan 6 butir pernyataan (contoh: "ketika bangun pagi, saya ingin segera berangkat ke kampus"), dedication dengan 5 butir pernyataan (contoh: "saya merasa bangga menjadi mahasiswa psikologi"), dan absorption dengan 6 butir pernyataan (contoh: "saya mampu konsentrasi penuh dalam belajar dan melupakan hal-hal di sekitar saya”). Kuesioner disusun dalam bentuk skala Likert dengan pilihan jawaban $\mathrm{SS}=$ sangat sesuai (4 poin), $\mathrm{S}=$ sesuai (3 poin), $\mathrm{TS}=$ tidak sesuai (2 poin), dan STS=sangat tidak sesuai (1 poin). Alat ukur UWES-SS 17 terdiri dari butir positif/favorable dan butir negatif/unfavorable. Berikut adalah blue print skala UWES 17 yang telah disebarkan kepada partisipan:

Tabel 1. Blue Print Skala UWES-SS 17

\begin{tabular}{cccc}
\hline Dimensi & Butir Favorable & Butir Unfavorable & Total \\
\hline Vigor & $1,7,8,13$ & 2,12 & 6 \\
Dedication & 9,14 & $3,4,15$ & 5 \\
Absorption & $5,6,10,16$ & 11,17 & 6 \\
\hline Total & 10 & 7 & 17 \\
\hline
\end{tabular}

Berdasarkan data pada table 1 dapat dapat dilihat bahwa butir pernyataan UWES-SS 17 adapatasi Indonesia terdiri dari butir favorable dan unfavorable. Namun, UWES-SS 17 versi aslinya tidak menggunakan butir pernyataan unfavorable. 
Tabel 2. Contoh Instrumen

\begin{tabular}{|c|c|c|}
\hline No. & Dimensi & Butir Pernyataan dan Nomor Urut \\
\hline 1 & Vigor & $\begin{array}{l}\text { a. Ketika bangun pagi, saya ingin segera berangkat ke kampus (1)+ } \\
\text { b. Ketika belajar, saya tidak mampu bertahan dalam waktu yang } \\
\text { lama (12)- }\end{array}$ \\
\hline 2 & Dedication & $\begin{array}{l}\text { a. Saya merasa bidang ilmu yang saya pelajari tidak bermakna dan } \\
\text { tidak dapat mencapai tujuan yang saya inginkan (3)- } \\
\text { b. Saya merasa bangga menjadi mahasiswa psikologi (14)+ }\end{array}$ \\
\hline 3 & Absorption & $\begin{array}{l}\text { a. Saya mampu konsentrasi penuh dalam belajar dan melupakan } \\
\text { hal-hal di sekitar saya (6)+ } \\
\text { b. Saya tidak menjiwai materi yang saya pelajari (11)- }\end{array}$ \\
\hline
\end{tabular}

\section{Prosedur}

Dalam proses adaptasi dan pengembangan alat ukur UWES-SS 17, peneliti melakukan tahapan, yaitu: (1) translation oleh ahli bahasa, (2) back translation, (3) adaptasi bahasa sesuai dengan kesesuaian bahasa Indonesia yang baik dan benar sehingga alat ukur dapat lebih dimengerti oleh partisipan, (4) face validity yang dilakukan kepada calon partisipan untuk memeriksa apakah partisipan mengerti isi dan kalimat dalam alat ukur, (5) content validity oleh expert judgement dilakukan untuk mendapat masukan dan penilaian dari ahli mengenai butir pernyataan yang ada apakah sudah mewakili dimensi dan indikator yang akan diukur, (6) pengumpulan data kepada partisipan, (7) pengolahan data berupa Uji Model CFA dengan menggunakan software M-Plus 7, dan (8) melakukan analisis data.

\section{HASIL DAN PEMBAHASAN Pembahasan}

Pada First Order Confirmatory Factor Analysis suatu variabel laten diukur berdasarkan beberapa indikator yang dapat diukur secara langsung. Perbedaan first order CFA dan second order CFA adalah pada second order CFA variabel laten tidak diukur langsung melalui indikator penilaian sedangkan first order CFA variabel laten diukur langsung melalui indicator (Sari \& Trijoyo, 2011).

Dalam uji model CFA menggunakan software M-plus index, kesesuaian model CFA dapat dilihat dari beberapa empat kriteria. Pertama, nilai Root Mean Square Error of Approximate (RMSEA). Root Mean Square Error of Approximate (RMSEA) diusulkan oleh Steiger dan Lind (1980, dikutip dalam Brown, 2006). Apabila nilai RMSEA $\leq 0,05$ menunjukkan close fit dan 0,05< RMSEA $\leq 0,08$, maka menunjukkan good fit. Kedua, nilai Tucker-Lewis Index /Non Normed Fit Index (TLI). Apabila nilai TLI berkisar antara 0 sampai 1, maka menunjukkan good fit. Ketiga, nila Comparative Fit Index (CFI). Apabila nilai CFI berkisar dari 0 sampai 1 menunjukkan good fit (Brown, 2006; Wijanto, 2008). Keempat, untuk pengukuran model CFA sendiri perlu melihat p-value dari model yang di uji. Apabila $p$-value lebih besar dari 0.05, maka model dianggap baik.

\section{Confirmatory Factor Analysis UWES-SS 17 Model 1 (First Order)}

Academic engagement memiliki tiga dimensi yaitu vigor, dedication, dan absorption. Dalam pengolahan data model 1, peneliti menguji model first order untuk melihat apakah butir pernyataan dapat mengukur dimensi sesuai dengan teori yang berlaku. Tabel 4 menunjukkan hasil uji CFA skala UWES-SS 17 untuk ketiga dimensi. 
Tabel 4. Data model 1 (first order) skala UWES-SS 17

\begin{tabular}{ccccc}
\hline Dimensi & P.Value & CFI & TLI & RMSEA \\
\hline Vigor & 0.2728 & 0.993 & 0.985 & 0.039 \\
\hline Dedication & 0.7781 & 1.000 & 1.014 & 0.000 \\
\hline Absorption & 0.9216 & 1.000 & 1.057 & 0.000 \\
\hline
\end{tabular}

Catatan: CFI=Comparative Fit Index; TLI=Tucker-Lewis Index; RMSEA=Root Mean

Square of Approximation

Berdasarkan data tabel 4 dapat dilihat bahwa dimensi vigor (P.value 0.2728, CFI 0.993, TLI 0.985, RMSEA 0.039), dedication (P.value 0.7781, CFI 1.000, TLI 1.014 RMSEA 0.000), absorption (P.value 0.9216, CFI 1.000, TLI 1.057, RMSEA 0.000) merupakan dimensi yang signifikan dan model good fit. Ketiga dimensi dikatakan fit dan bekerja sesuai dengan teori academic engagement. Pada model satu ini, setiap butir pernyataan diuji untuk melihat apakah butir-butir tersebut mampu mengukur dimensi dan indikator yang ada. Setiap dimensi telah diuji model dan hasilnya terlihat dari tabel berikut ini:

Tabel 5. Data model 1 (first order) butir pernyataan perdimensi

\begin{tabular}{ccccc}
\hline Dimensi & Es & S.E & T.Value & P.Value \\
\hline Vigor & & & & \\
Butir 1 & 0.411 & 0.082 & 5.004 & 0.000 \\
Butir 2 & 0.709 & 0.064 & 11.115 & 0.000 \\
Butir 7 & 0.533 & 0.084 & 6.360 & 0.000 \\
Butir 8 & 0.652 & 0.072 & 9.019 & 0.000 \\
Butir 12 & 0.726 & 0.047 & 15.371 & 0.000 \\
Butir 13 & 0.475 & 0.074 & 6.388 & 0.000 \\
& & & & \\
\hline Dedication & & & & 0.000 \\
Butir 3 & 0.749 & 0.052 & 14.446 & 0.000 \\
Butir 4 & 0.733 & 0.052 & 14.128 & 0.000 \\
Butir 9 & 0.603 & 0.056 & 10.849 & 0.000 \\
Butir 14 & 0.726 & 0.055 & 13.300 & 0.014 \\
Butir 15 & 0.241 & 0.098 & 2.461 & \\
& & & & 0.000 \\
Absorption & & & & 0.000 \\
Butir 5 & 0.566 & 0.076 & 7.453 & 0.000 \\
Butir 6 & 0.466 & 0.075 & 6.193 & 0.000 \\
Butir 10 & 0.597 & 0.079 & 7.549 & 0.000 \\
Butir 11 & 0.705 & 0.074 & 9.504 & 0.000 \\
Butir 16 & 0.406 & 0.091 & 4.456 &
\end{tabular}

Catatan: Es=Estimate; S.E=Standard Error;

Dalam pengukuran statistik, nilai estimate (loading factor) butir pernyataan dinyatakan signifikan apabila nilai t-hitung $(t$-value $)>\mathrm{t}$-tabel $(1,96)$. Nilai ini menunjukkan bahwa indikator penyusun dapat menjelaskan variabel latennya. Berdasarkan data pada tabel 5 dapat dilihat dari 17 butir pernyataan yang diujikan, 16 butir pernyataan yaitu butir 1, 2, 7, 8, 12, 13 (vigor), 3, 4, 9, 14 (dedication), dan 5, 6, 10, 11, 16, 17 (absorption) memiliki estimate lebih dari 0.3, P.Value 
kurang dari 0.05, T.Value lebih dari 1.96 dan nilainya tidak minus sehingga 16 butir tersebut dikatakan signifikan dan fit dalam mengukur masing-masing dimensi.

Sedangkan untuk butir 15 (dedication) meskipun memiliki nilai estimate dibawah 0.3, namun nilai P.Value tetap kurang dari 0.05, T.Value lebih dari 1.96 dan nilainya juga tidak minus sehingga butir 15 tetap dianggap signifikan dan fit dalam mengukur dimensi dedication. Dengan demikian, hasil uji CFA first order untuk setiap dimensi menunjukkan nilai yang fit dan signifikan. Tidak ada butir pernyataan yang tidak signifikan dan tidak mengukur dimensi sehingga setiap dimensi dapat mewakili teori academic engagement. Gambar 1 hingga 3 merupakan path diagram untuk hasil uji CFA first order setiap dimensi.

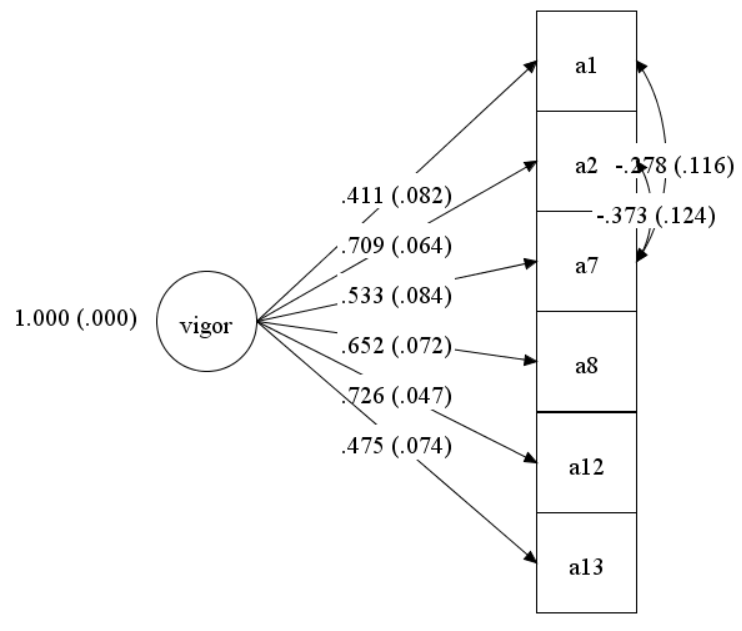

Gambar 1: Path diagram model 1 (first order) dimensi vigor

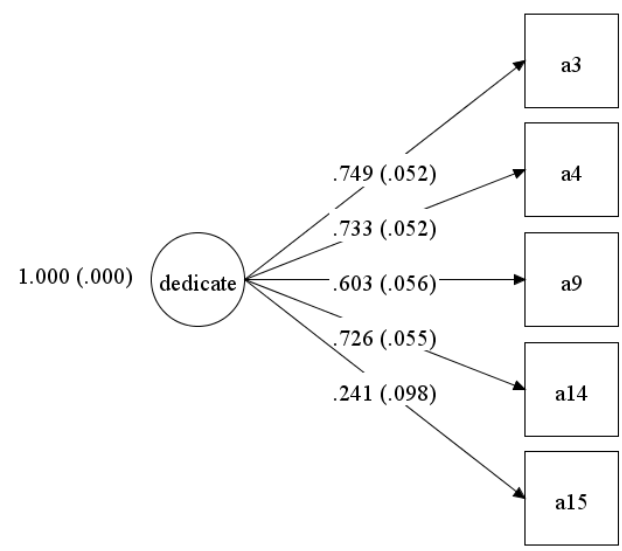

Gambar 2: Path diagram model 1 (first order) dimensi dedication 


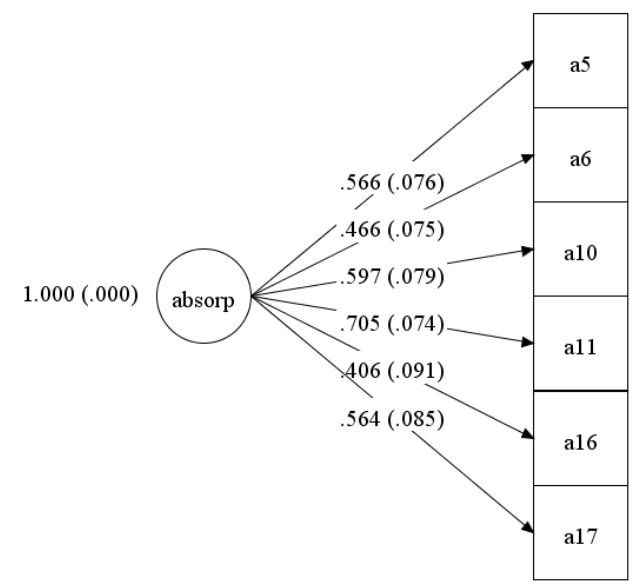

Gambar 3: Path diagram model 1 (first order) dimensi absortion

Confirmatory Factor Analysis UWES-SS 17 Model 2 (Second Order)

Berdasarkan hasil uji model 2 second order terhadap alat ukur UWES-SS 17, maka didapatkan hasil P.value 0.0737, CFI 0.982, TLI 0.977, RMSEA 0.035, maka model ini merupakan model good fit.

Tabel 6. Data model 2 (second order) UWES-SS 17

\begin{tabular}{ccccc}
\hline Dimensi & Es & S.E & T.Value & P.Value \\
\hline Vigor & & & & \\
Butir 1 & 0.385 & 0.069 & 5.599 & 0.000 \\
Butir 2 & 0.671 & 0.050 & 13.524 & 0.000 \\
Butir 7 & 0.356 & 0.077 & 4.598 & 0.000 \\
Butir 8 & 0.568 & 0.068 & 8.413 & 0.000 \\
Butir 12 & 0.766 & 0.039 & 19.660 & 0.000 \\
Butir 13 & 0.561 & 0.075 & 7.520 & 0.000 \\
\hline Dedication & & & & \\
Butir 3 & 0.724 & 0.045 & 15.986 & 0.000 \\
Butir 4 & 0.724 & 0.051 & 14.202 & 0.000 \\
Butir 9 & 0.725 & 0.050 & 14.363 & 0.000 \\
Butir 14 & 0.429 & 0.066 & 7.400 & 0.000 \\
Butir 15 & 0.106 & 0.100 & 1.065 & 0.287 \\
Butir 5 & & & & 000 \\
Butir 6 & 0.606 & 0.060 & 10.132 & 0.000 \\
Butir 10 & 0.480 & 0.062 & 7.724 & 0.000 \\
Butir 11 & 0.519 & 0.072 & 7.258 & 0.000 \\
Butir 16 & 0.740 & 0.058 & 12.850 & 0.000 \\
Butir 17 & 0.322 & 0.077 & 4.178 & 0.000 \\
Vigor & 0.566 & 0.064 & 8.895 & 0.000 \\
Dedication & 1.003 & & & 0.000 \\
Absorption & 0.824 & 0.050 & 19.910 & 0.000 \\
\hline Cation & 1.089 & 0.050 & 16.443 & 21.567 \\
\end{tabular}

Catatan: Es=Estimate; S.E=Standard Error; 
Berdasarkan data pada tabel 6 dapat dilihat bahwa model 2 second order menunjukkan hasil yang tidak jauh berbeda dengan hasil model 1 first order. Dari 17 butir pernyataan yang diujikan, 13 butir pernyataan yaitu butir 1, 2, 7, 8, 12, 13 (vigor), 3, 4, 9, 14 (dedication), dan 5, 6, 10, 11, 16, 17 (absorption) memiliki estimate lebih dari 0.3, P.Value kurang dari 0.05, T.Value lebih dari 1.96 dan nilainya tidak minus sehingga 16 butir tersebut dikatakan signifikan dan fit dalam mengukur masing-masing dimensi. Perbedaannya terletak pada nilai butir 15 (dedication). Pada model 1 first order, butir 15 masih dapat dikatakan fit meskipun nilai estimate-nya di bawah 0.3 karena nilai P.Value tetap kurang dari 0.05, T.Value lebih dari 1.96 dan nilainya tidak minus. Pada model 2 second order, nilai estimate butir 15 tetap berada di bawah 0.3, yaitu 0.106, tetapi butir ini menjadi tidak signifikan karena nilai P.Value tetap lebih dari 0.05 (0.287) dan T.Value kurang dari 1.96 (1.065). Dengan demikian, butir 15 dianggap tidak signifikan dan tidak mengukur dimensi sesuai dengan teori academic engagement. Selain melihat signifikansi setiap butir pernyataan, model second order juga melihat signifikansi setiap dimensi dalam mengukur UWES-SS 17 sesuai dengan teori. Berdasarkan data pada tabel 6 dapat dilihat bahwa ketiga dimensi memiliki nilai yang signifikan dan fit untuk mengukur UWES-SS 17 sesuai dengan teori academic engagement. Gambar 4 merupakan path diagram model 2 second order dari academic engagement.

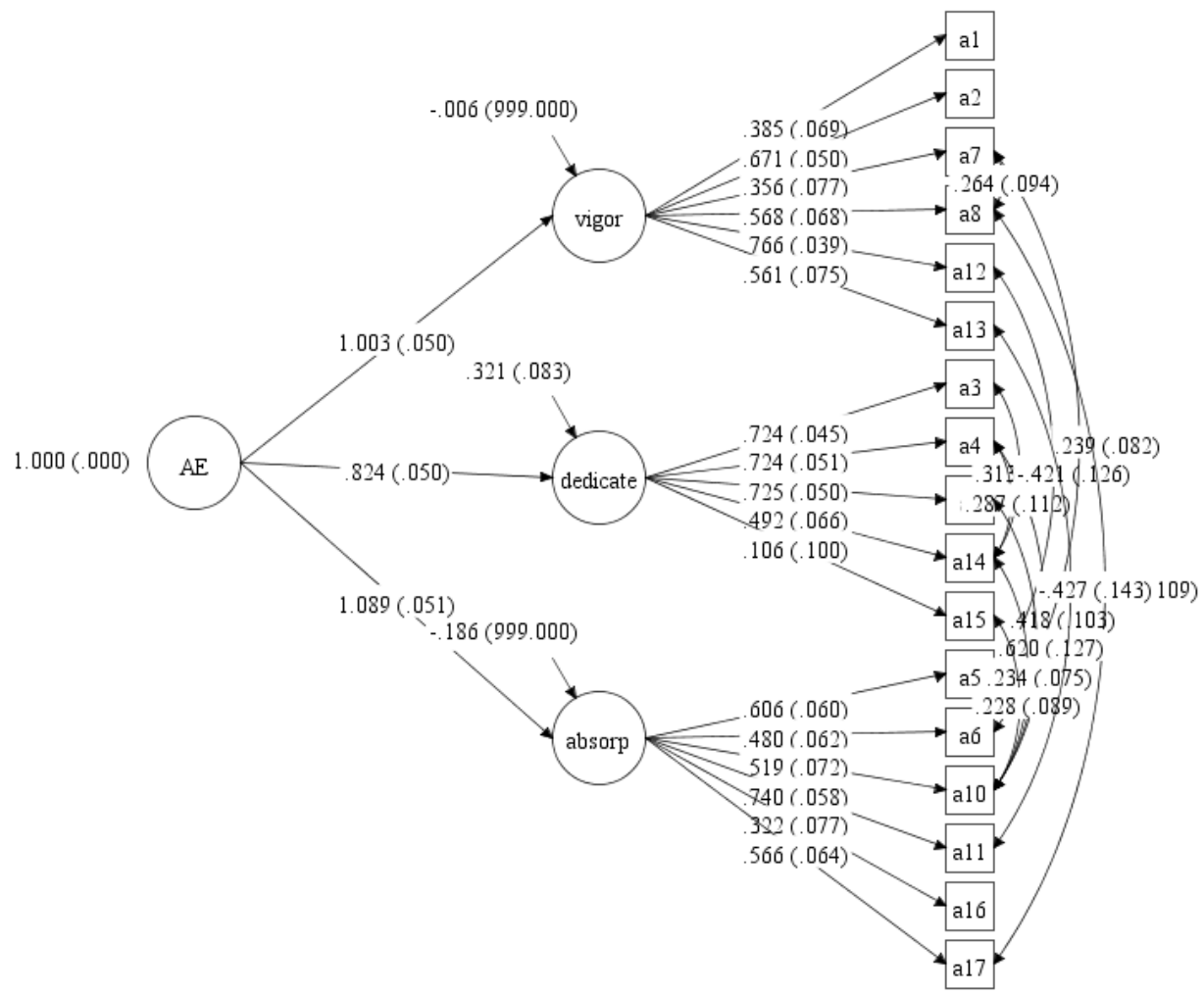

Gambar 4: Path diagram model 2 (second order)

\section{KESIMPULAN DAN SARAN}

\section{Kesimpulan}

Berdasarkan hasil analisis data CFA terhadap model 1 (first order) dan model 2 (second order), dapat disimpulkan bahwa dari 17 butir pernyataan yang diajukan kepada partisipan, 16 butir di antaranya memiliki nilai yang signifikan dan model fit untuk mengukur masing-masing dimensi. Hanya ada satu butir pernyataan yaitu butir 15 (dedication) yang drop dan tidak dapat mengukur atau mewakili dimensinya pada uji model 1. Dengan demikian, butir 15 tidak perlu dimasukan ke dalam instrument untuk pengukuran berikutnya. 
Berdasarkan hasil model 2 (second order) dapat disimpulkan bahwa ketiga dimensi dari alat ukur UWES-SS 17, yaitu vigor, dedication, dan absorption memiliki nilai yang signifikan dan model fit untuk mengikut UWES-SS 17. Dengan demikian, alat ukur UWES-SS 17 merupakan alat ukur yang representatif dan efisien untuk mengukur variable academic engagement pada mahasiswa Fakultas Psikologi UIN Jakarta. Data dan hasil yang didapatkan dari alat ukur UWES-SS 17 mampu menggambarkan bagaimana tinggi rendahnya academic engagement pada mahasiswa Fakultas Psikologi UIN Jakarta.

\section{Saran}

Bagi peneliti selanjutnya disarankan untuk menggunakan teknik pengambilan sampel dengan teknik yang lebih baik seperti stratified random sampling sehingga lebih baik dalam mewakili populasi secara keseluruhan. Peneliti selanjutnya juga perlu membahas lebih dalam mengenai perbandingan signifikansi setiap butir yang mengalami perubahan nilai, serta membahas pula korelasi antar butir yang mengukur lebih dari satu dimensi sehingga kondisi alat ukur tergambarkan dengan lebih baik.

\section{Ucapan Terima Kasih (Acknowledgement)}

Ucapan terima kasih penulis sampaikan kepada Fakultas Psikologi disalah satu universitas negeri di Tangerang Selatan beserta mahasiswanya yang telah bersedia memberikan kesempatan dan waktu kepada peneliti untuk mengambil data. Terima kasih pula disampaikan kepada Ibu Zulfa Indira Wahyuni, M.Psi., Psikolog dan Ibu Solicha, M.Si yang telah mengizinkan peneliti mengambil data pada mata kuliahnya. Terakhir peneliti mengucapkan banyak terima kasih kepada Ulfa Rizkiana, S.Psi dan Citra Febriyanti, S.Psi yang telah membantu peneliti dalam proses pengumpulan dan pengolahan data.

\section{REFERENSI}

Alarcon, G. M., Edwards, J. M., and Menke, L. E. (2011). Student burnout and engagement: A test of the conversation of resources theory. The Journal of Psychology, 145 (3), pp. 211227.

Alrashidi, O., Phan, H. P., and Ngu, B. H. (2016). Academic engagement: An overview of its definitions, dimensions, and major conceptualisations. International Education Studies, 9 (2).

Aslamawati,Y., Enoch., dan Halimi, A. (2015). Hubungan college engagement dengan prestasi akademik mahasiswa muslim di bandung. Psympathic, Jurnal Ilmiah Psikologi, 2 (1), pp. 25-31.

Balducci, C., Fraccaroli, F., and Schaufeli, W. B. (2010). Psychometric properties of the italian version of the Utrecht work engagement scale (UWES-9) a cross-cultural analysis. European Journal of Psychological Assessment, 26 (2), pp. 143-149.

Brown, T. A. (2006). Confirmatory factor analysis for applied research. New York, NY: The Guilford Press

Ouweneel, E., Blanc, P. M. L., and Schaufeli, W. B. (2014). On being grateful and kind: result of two randomized controlled trials on study-related emotions and academic engagement. The Journal of Psychology, 148 (1), pp. 37-60.

Ouweneel, E., Schaufeli, W. B., \& Blanc, P. M. L. (2013). Believe, and you will achieve: changes over time in self-efficacy, engagement, and performance. Applied psychology: health and well-being, 5(2), pp. 225-247. 
Salanova, M., Schaufeli, W. B., Martínez, I., \& Bresó, E. (2010). How obstacles and facilitators predict academic performance: the mediating role of study burnout and engagement. Anxiety, Stress, \& Coping, 23, pp. 53-70.

Salmela-Aro, K., and Upadyaya, K. (2014). School burnout and engagement in the context of demands-resources model. British Journal of Educational Psychology, 84, pp. 137-151.

Sari, N. I. dan Trijoyo, J. D. (2011). Confirmatory factor analysis untuk mengukur unidimensional indikator performa pengelolaan lingkungan hidup dalam survei publik otonomi award jawa pos institute of pro otonomi tahun 2011. Jurnal Institut Teknologi Sepuluh Nopember (ITS). 1(1). pp. 93-94.

Schaufeli, W. B., Martinez, I.M., Pinto, A. M., Salanova, M., and Bakker, A. B. (2002). Burnout and engagement in university student: a cross-national study. Journal of Cross-Cultural Psychology, 33, pp. 464-481.

Schaufeli, W. B., Salanova, M., Roma, V. G., and Bakker, A. B. (2001). The measurement of engagement and burnout: a two sample confirmatory factor analytic approach. Journal of Happiness Studies, 3, pp. 71-92.

Seppala, P., Mauno, S., Feldt, T., Hakanen, J., Kinnumen, U., Tolvanen, A., and Schaufeli, W. B. (2009). The construct validity of the Utrecht work engagement scale: multiple and longitudinal evidence. Journal Happiness Study, 10, pp. 458-481.

Shih, S. S. (2012). An examination of academic burnout versus work engagement among Taiwanese adolescents. The Journal of Educational Research, 105, pp. 286-298

Soini, H.T., \& Salmela-Aro, K. (2013). Schoolwork engagement and burnout among finnish high school student and young adults: profiles, progression, and educational outcomes. Developmental Psychology, 50 (3), pp. 649-662.

Stoeber, J., Childs, J. H., Hayward, J. A., and Feast, A. R. (2011). Passion and motivation for studying: predicting academic engagement and burnout in university students. Educational psychology, 31 (4), pp. 513-528.

Titien. (2016). Penyusunan dan pengembangan alat ukur employee engagement. Psikohumaniora: Jurnal Penelitian Psikologi, 1 (1), pp. 113-130

Wijanto, S. H. (2008). Structural equation model. Yogyakarta : Graha Ilmu.

Zhang, S., Shi, R., Yun, L., Li, X., Wang, Y., He, H., and Miao, D. (2014). Self-regulation and study-related health outcomes: a structural equation model of regulatory mode orientation, academic burnout and engagement among university students. Social Research. 